\title{
Analysis of factors Affecting Project Delay in PT Telkom Property Viewed from Owner Factors, Contractor Factors and External Factors
}

\author{
Rosalendro Eddy Nugroho, Farida Elmi, Wahyu Oktri Widyarto
}

\begin{abstract}
In the process of construction there is a complex lead to the possibility of delays in project completion. The emergence of project completion delays may be caused by the parties involved in the implementation of the project that is owner factors, contractor factors, and other external factors that are also related to the implementation of the project. This research was conducted in order to determine the causes of delays in project implementation in terms of owner factors, contractor factors, and external factors on PT. Telkom Property. Conducted by distributing questionnaires to contractors, owners and subcontractors, the results obtained were processed using rank analysis. This study concluded that the factors causing delays in the completion of projects at PT. Telkom Property the most dominant contractor factors, have the rank order (ranking) as follows: (1) deficiencies in the provision of human resources, (2) failure of schedule planning, (3) a shortage in the supply of money, (4) failure of site coordination, (5) shortage in the provision of material, (6) a shortage in the supply of tools, and (7) shortages in the supply of sub-contractors.
\end{abstract}

Index Terms - Project Delays, Factors that Causing The Projects Delays, Ranking.

\section{INTRODUCTION}

The definition of delay is a portion of the implementation time that cannot be utilized in accordance with the plan, causing some of the activities that follow to be delayed or cannot be completed precisely according to the planned schedule (Ervianto, 2014; p116). Project delays can be caused by the contractor, the owner, or caused by natural and environmental conditions beyond human capability or called force PT. TELKOM PROPERTY is a subsidiary of PT. TELKOM, Tbk. which is engaged in building management and construction management. PT. TELKOM PROPERTY especially the Construction Management division handles several projects such as hotel construction, office building renovation, office building construction, and all of them are still within the scope of the Telkom Group. Most of the

Rosalendro Eddy Nugroho, Master of Management Program, Universitas Mercu Buana, Jakarta, Indonesia

Farida Elmi, Master of Management Program, Universitas Mercu Buana, Jakarta, Indonesia

Wahyu Oktri Widyarto, Industrial Engineering Department, Universitas Serang Raya, Banten, Indonesia construction projects handled by PT. TELKOM PROPERTY, there are several projects that experience delays as shown in the picture..

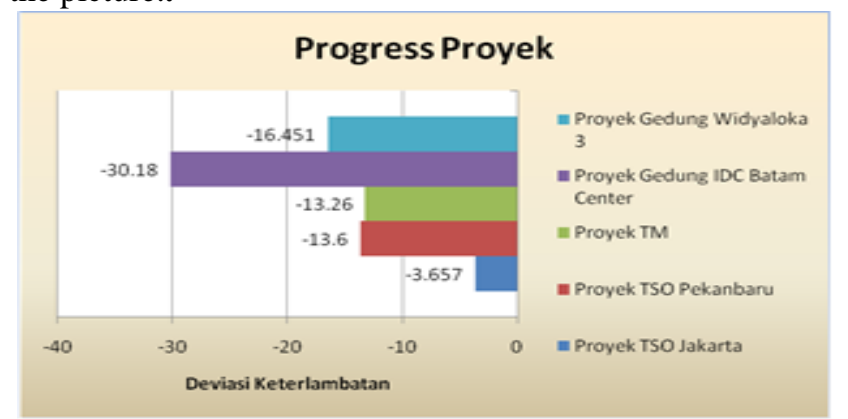

Figure 1. Project Progress of PT. Telkom Property Period 2014 - 2015

Figure 1 shows the target completion time of several projects handled by PT. Telkom Property is experiencing a time delay. In the Widyaloka 3 Building project. Of the $100 \%$ progress planned, the progress carried out has only reached $83,549 \%$, so there is a deviation of $-16.451 \%$, In the IDC Batam Center Building project. of $-30.18 \%$, in the Transportation Management Building project. Of the $100 \%$ planned progress the progress carried out has only reached $86.74 \%$, so there is a deviation of $-13.26 \%$, the Pekanbaru TSO project of the $100 \%$ progress planned for the progress carried out has only reached $86.42 \%$, so there is a deviation of $-13.6 \%$. In the Jakarta TSO project, from the $100 \%$ progress planned, the progress made has only reached $96,342 \%$, so there is a deviation of $-3,657 \%$. Companies often get into trouble when completing projects because the completion time is not in accordance with the agreed time beforehand. This will adversely affect the company, including worsening the image of companies that seem unable to complete the project according to the agreed contract. In addition the company will incur more costs with inappropriate project completion time. Therefore we need an analysis of the factors that influence project delays so we can know the things that cause delays in project completion.

\section{LITERATUR REVIEW}

Standard contract documents, published by AIA (American Institute of Architects) (1997), distinguish project delays into 2 groups: Excusable / compensable is a reasonable delay and can be compensated. Cases of delay that are reasonable and can be compensated for are delays caused by the owner in relation to being unable to provide travel to the project, changes in plan drawings, changes in the scope of 
contractor work, delays in approving work drawings, schedules, and materials, lack of coordination and field supervision, payment pending, interference from the owner who is not in authority. In this case the contractor is entitled to an extra time and cost dispensation. Non Excusable / noncompensable is a reasonable delay, but cannot be compensated. Cases of delays that are reasonable, but cannot be compensated for are delays that are beyond the capabilities of both the contractor and the owner. For example, bad weather, fires, floods, labor strikes, wars, destruction by others, work prohibitions, epidemics, inflation / escalation in prices and so on. This case is usually called force majeure.

According to Haq (2013, the S curve is a graph developed by warren T. Hanumm on the basis of observing a large number of projects from the beginning to the end of the project. Curve s can show the progress of the project based on the activity, time and weight of work represented as a cumulative percentage of all activities. Visualization of the $S$ curve can provide information about the progress of the project by comparing it to the planned schedule. From this it is known whether there is a delay or acceleration of the project schedule.(Ahmad, 2015) These indications can make preliminary information to make corrective actions in the schedule control process. But the information is not detailed and is only limited to assessing project progress. Further improvements can use other methods that are combined, for example the beam chart method or network planning by renewing resources and time in each activity .(Pourrostam, T 2013)

\section{A. Formulation of The Problem}

In the construction process of a project, there are three barriers which are often called triple constraints:

1. Project Costs must be completed with costs that do not exceed the budget. Budgets that are consistent with the original plan often do not occur due to delays in the project. But usually to minimize costs can be done an anticipation, for example the addition of working hours, the addition of labor and turnover.

2. Project schedule must be carried out in accordance with the specified time period and end date. but if there is a delay in activity it will definitely cause an extension of time, and in the end it can lead to an extension of time for the whole project.

3. Product Quality produced in the project must meet the required specifications and criteria because if not, the image / good name of the contractor will decrease to the project owner.

Based on the background description of the problem above, the problem formulation of this research are:

1). What factors are causing the project delay in PT. Telkom Property in terms of owner factors, contractor factors, and external factors.

2). What are the most dominant project delay factors that influence project delay at PT. Telkom Property in terms of owner factors, contractor factors, and external factors.

Capitalize only the first word in a paper title, except for proper nouns and element symbols. For papers published in translation journals, please give the English citation first, followed by the original foreign-language citation [8].

\section{B. Research Purposes}

1).Analyze in terms of owner factors, contractor factors, and the most dominant external factors causing project delays at PT. Telkom Property.

2). Analyzing the ranking of the project delay factors in terms of owner factors, contractor factors, and external factors that are the most dominant influence the project delay at PT.

Telkom Property.

\section{METHOD}

Population used in this study are individuals as owners and implementers of 5 projects handled by PT. Telkom Property, amounting to 688 people and holding positions as Top Management, Field Managers, Supervisors, and Implementers. To determine the number of samples to be used is calculated by the Slovin formula (Shahid, 2015):

$$
n=\frac{N}{1+n e^{2}}
$$

Where,

$\mathrm{n}$ : number of samples

$\mathrm{N}$ : total population

e: error tolerance limit

With an error tolerance limit of 5\%, then: $n=252,94 \sim 253$

\section{A.Determine Score Against Questionnaire Statements}

After the statements - statements are determined, then the next step is to determine the score for these statements. In this study, the measurement scale of the data has an ordinal scale that shows differences in the level of subjects quantitatively, such as data expressed in the form of ranking or ranking. Respondents' perceptions can be sorted into: No influential, somewhat influential, influential and very influential. Then the quantitative data is changed to quantitative data as follows: No effect is given a value of 0 ; rather influential rated 1 ; influential rated 2 ; very influential rated 3 .

\section{B.Determining the Ranking of Respondents' Answers}

To determine the ranking or ranking of the factors causing delays in the project PT. Telkom Property in general on the answers of respondents analyzed with an index of importance based on the average value of the respondents' perceptions (Gasperz,):

$$
\text { Mean }=I=\sum_{1}^{4}=1 \frac{\text { aixi }}{N}
$$

With: $\mathrm{I}=$ Interest $($ B $)$ dex

$\mathrm{Xi}=$ frequency of response of each perception

$\mathrm{X} 1=$ answer frequency has no effect

$\mathrm{X} 2$ = frequency of the answer is rather influential

$\mathrm{X} 3$ = frequency of influential answers

$\mathrm{X} 4$ = frequency of answers is very influential

$\mathrm{ai}=$ value of given perception $(0.1,2,3)$

$\mathrm{N}=$ amount of data

\section{C.Pareto diagram}

Pareto diagram is one of the tools (tools) of QC 7 Tools that are often used in terms of Quality control. Basically, a Pareto Diagram is a bar graph that shows problems based on the order of the number of events. The sequence starts from the number of problems that occur the most until the least 
occurs. In the graph, indicated by the highest bar graph (far left) to the lowest graph (far right). In its application, Pareto Diagrams are very useful in determining and identifying priority problems to be solved. The most frequent and frequent problems are our highest priority for action.

\section{D.Variable Identification}

To identify or determine the factors of delay that will be examined in this study, researchers took references from the final project report made by the project team of PT. Telkom Property. Because basically PT. Telkom Property is a subsidiary of Telkom that manages all assets and development development at the Telkom Group, so in its position if PT. Telkom property is handling projects within PT. Telkom Property itself, then its position is as the owner. And if PT. Telkom Property is handling projects in other Telkom subsidiaries in the Telkom Group, so its position is as a contractor. In the implementation of the project, PT. Telkom Property is always associated with subcontractors and licensing with the local government, for that reason the author reviewed the project delay from the owner factor, contractor factor, and external factors. Furthermore, after obtaining reference to the factors of delay in the project of PT. Telkom Property, researchers compare with previous studies. According to Alaghbari (2007, p3) the variable delay factors can be identified as follows:

Owner Factors, consisting of 8 subfactors:

- Cannot provide travel to the project (X1)

- Change of plan image (X2)

- Changes in the scope of work of the contractor (X3)

- Delay in approving work drawings (X4)

- Schedules and materials (X5)

- Lack of coordination and field supervision (X6)

- Payment pending (X7)

- Interference of owner of non-authority (X8)

Contractor Factors, consisting of 8 subfactors:

- Lack of human resources supply (X9)

- Lack of equipment (X10)

- Lack of material supply (X11)

- Deficiencies in providing subcontractors (X12)

- Lack of money supply (X13)

- Field coordination failure (X14)

- Failure of schedule planning (X15)

- Low productivity (X16)

External factors, consisting of 9 subfactors:

- Bad weather (X17)

- Fire (X18)

- Flood (X19)

- Labor strike (X20)

- Damage by other parties (X21)

- Prohibition of work (X22)

- Outbreaks of disease (X23)

- Price inflation / escalation (X24)

- Project completion is not on target (X25)

\section{RESULT AND DISCUSSION}

In this section item the factors causing the delay in project completion at PT. Telkom Property is calculated using the calculation of the importance index so it is known the ranking or ranking of items from the respondent's answer with the formula (2): As an example of calculating the average value (Mean), then an index of interest is sought, i.e..

$$
\operatorname{Mean}(X 12)=\frac{(0 \times 3)+(1 \times 0)+(2 \times 5)+(3 \times 42)}{50}=2,72
$$

By using the same calculation, the mean / average for each of the subfactors causing project delays at PT. Telkom Property can be calculated.

Table 1. Ranking of Factors Cause for Project Completion

Average Rating Delay Factor

Deficiencies in the supply of human resources $2.94 ; 1$

Failure of schedule planning 2.9; 2

Shortages in providing money $2.86 ; 3$

Failure of field coordination 2,82; 4

Lack of material supply 2,8; 5

Labor strikes 2.78; 6

Lack of tools provision 2.76; 7

Schedules and materials $2.74 ; 8$

Shortages in providing subcontractors $2.72 ; 9$

Delay in approving work drawings $2.68 ; 10$

Bad weather 2.66; 11

Price inflation / escalation $2.64 ; 12$

Project completion did not meet target 2.62; 13

Fire 2.58; 14

Unable to provide road to project $2.56 ; 15$

Payment pending $2.52 ; 16$

Intervention of owners who do not have the authority $2.48 ; 17$

Plague $2.46 ; 18$

Flood 2.42; 19

Destruction by other parties 2,$4 ; 20$

Low productivity 2,$34 ; 21$

Prohibition of work $2.26 ; 22$

Change in drawing plan $2.24 ; 23$

Changes in the scope of work of contractors $2.18 ; 24$

Lack of coordination and field supervision 2.04; 25

Source: Data processed, 2017

The table shows 25 factors that cause delays in project completion at PT. Telkom Property that has been sorted by ranking 1-25 based on the mean (importance index). Next to give an assessment of the average price, the following limitations are made: the average price is less than 0.50 (no effect), 0.51 - 1.49 (somewhat influential), 1.50 - 2.49 (influential) , 2.50 - 3.00 (highly influential).

By using the table reference the 25 factors causing project delays that have a value interval of 2.51 - 3.00 (very influential) are selected, after ranking they are ranked 1 through 16, 16 (sixteen) factors are: (1) Weaknesses in provision of human resources, (2) Failure of schedule planning, (3) Lack of money supply, (4) Failure of field coordination, (5) Lack of material supply, (6) Labor strikes, (7) Lack of equipment, (8) Schedule and materials, (9) Lack of sub-contractor provision, (10) Delay in approving work drawings, (11) Bad weather, (12) Inflation / escalation of prices, (13) Completion of projects not on target, (14) Fires, (15) Unable to provide travel to the project, (16) Payment is delayed. which has interval values between $2.51-3.00$ and are ranked sequentially.

After the cause of each factor is known, the researcher then conducts an interview with respondents totaling 250 people, 


\section{Analysis of factors Affecting Project Delay in PT Telkom Property Viewed from Owner Factors, Contractor Factors and External Factors}

to choose 1 (one) cause from 16 (sixteen) causal factors which according to them are the most dominant or often occur.

From table 3 it can be seen that the 16 factors that were most chosen by respondents after being sorted by the largest number were: lack of human resources (45), lack of material (36), lack of equipment (30), Failure of schedule planning (27), Lack of sub-contractor provision (20), Lack of money supply (19), Failure of field coordination (12). Of the seven factors that cause one major factor, namely the contractor factor. Thus these factors are indeed often experienced by project implementers of PT. Telkom Property, so that if these things occur, then project work cannot be directly carried out.

Table 2. Sixteen Factors for Project Delay based on the ranking to be chosen by respondents

No. Factors Causing Project Delay Number of respondents

1 Lack of HR provision 45

2 Failure to plan schedules 27

3 Lack of money supply 19

4 Failure of field coordination 12

5 Lack of material supply 36

6 Labor strikes 3

7 Lack of tools 30

8 Schedule and material 2

9 Deficiencies in the provision of subcontractors 20

10 Delay in approving work drawings 2

11 Bad weather 10

12 Price inflation / escalation 5

13 Project completion did not meet target 9

14 Fire 4

15 Cannot provide a road to project 10

16 Payment delayed 16

Total Respondents are 250 amount

Source: Data processed, 2017

The following is a contractor's pareto diagram which includes these factors:

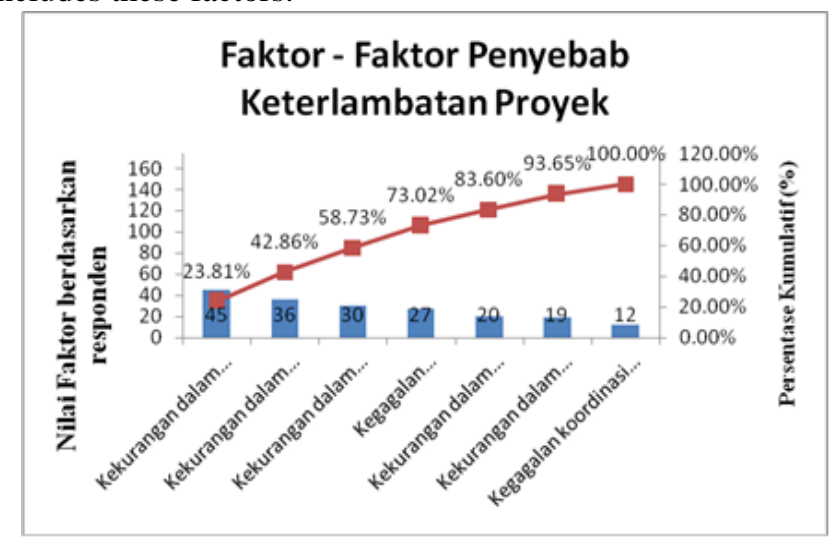

Figure 3. Pareto Diagram of Factors Causing Delay

(Source: Data processed, 2017)

Based on the cause and effect diagram, it is known that the highest cause of delay is $20 \%$ of all the delay factors. The principle of the program is that $80 \%$ of the problems come from $20 \%$ of the causes, so if you can solve $20 \%$ of the causes then you can solve $80 \%$ of the delay. In this Pareto diagram the causes of delay can be seen in order from the highest on the left to the lowest on the right. In the case of delays in the completion of this project, the most frequent cause of delay is the lack of human resources, therefore project managers need to take policies or corrective actions such as increasing cooperation with the labor market.

\section{CONCLUSION}

Based on the analysis of project delays in terms of the Owner factor, Contractor factors and External factors that cause delays in project completion at PT. Telkom Property with the data obtained by researchers, the conclusions can be drawn as follows:

After analyzing the ranking of several variables of owner factors, contractor factors, and external factors chosen by respondents as factors causing project delays at PT. The most dominant Telkom Property obtained rankings as follows: (1) lack of human resources, (2) failure of schedule planning, (3) lack of money supply, (4) failure of field coordination, (5) lack of material supply, (6) ) deficiencies in the supply of equipment, and (7) deficiencies in the provision of subcontractors. The seven variables represent one factor, the contractor factor The main factors causing the delay in project implementation at PT. Telkom Property from contracting factors are:

Shortages in the supply of human resources, this is because the amount of labor needed in each stage of project implementation varies, depending on the size and type of work. Deficiencies in the provision of human resources in the field can cause problems because labor is a resource that is not easily obtained and is very expensive.

Failure to plan schedules, this is because in the preparation of the initial project schedule that must be done is the identification of project activities. Incomplete identification will affect the overall project duration and disrupt the work order.

Lack in providing money, this is because the contractor does not have sufficient funding backup, before the contractor asks for payment to the contractor owner must be able to bail out funding in advance for the purchase of material, and also payment of workers' wages. After the work progress is achieved in accordance with the agreement written in the contract, the contractor can collect payment from the owner

Failure of field coordination, this is due to miscommunication between field supervisors and workers. Based on observations in the field there was an incorrect specification of the material installed by the workers so that they had to re-demolish the work.

Lack of material supply, based on observations in the field the need for material control in the form of schedules for each type of work, because there is a schedule means controlling time so that no material delays occur. Material procurement must take into account when the implementation of the work items is started, therefore the material procurement schedule must be based on the work implementation schedule.

shortages in the supply of equipment, this is due to delays in supplier shipments, difficulty in getting it, and lack of material itself. The provision of tools and materials that are not in accordance with the needs and planned time, will make workers' productivity decrease due to the number of unemployed hours, thus hampering the pace of work. 
shortcomings in providing subcontractors, this is due to the lack of workers / workers who have the expertise and experience in completing work in the field. For work that is general, for example; Soil excavation, Install the foundation below there are no significant difficulties, but for jobs that involve engineering capabilities there are still very few experts who have certified expertise or subcontractors in specialized fields.

\section{SUGGESTION}

A Based on the conclusions above, the researcher can provide some suggestions addressed to the project owner and contractor that may be used as input for the company for the future, namely as follows:

It is better for project managers to take policies or remedial actions such as increasing cooperation with the labor market both private and government to meet the shortage of quality human resources so as to increase work productivity so that they can complete project work on time.

The owner and contractor should look at other factors, although according to the Pareto principle only $20 \%$ causes delays that can cause $80 \%$ delays, but it does not rule out other factors can cause project delays.

Because in this study examines the factors that cause delays in the completion of construction projects from the owner factor, contractor factors, and external factors, it is necessary to examine the delay factor of building project completion from other factors such as factors of design consultants, supervisory consultants, and also of several factors causing project delays such as (1) lack of human resources, (2) failure of schedule planning, (3) lack of money supply, (4) failure of field coordination, (5) lack of material supply, (6) lack of equipment, and (7) shortcomings in the provision of subcontractors because most of the projects as the researchers suspect make the seven things mentioned above as the main reason for delays in project completion.

\section{REFERENCES}

[1] Ahmad. (2015) "analysis of key performance factors affecting residential construction projects in pakistan." Arabian Journal of Business and Management Review (Nigerian Chapter). Vol. 3, No. 10, 2015

[2] Alaghbari, M. R. A. (2007). "The significant factors causing delay of building construction projects in Malaysia, " Engineering, Construction and Architectural Management, vol. 14, , p.3, Nov 2007

[3] Ervianto, Wulfram I, 2014, Theory - Construction Project Management Applications, Yogyakarta, Andi Offset.

[4] Gaspersz, V. and A. Fontana. 2011. Integrated Management Problem Solving Guide for Business and Industry Practitioners. Vinchristo Publication Publisher

[5] Haq, Y. and Aslam, M., 2013. Causes of Delay in Construction Projects of Punjab-Pakistan: an empirical study. Journal of Basic and Applied Scientific Research, 3(10), pp.87-96

[6] Pourrostam, T. dan Ismail, A., 2012. Causes and effects of delay in Iranian construction projects. International Journal of Engineering and Technology, 4(5), p.598.

[7] Shahid Aysha, et al. "analysis of key performance factors affecting residential [8] construction projects in pakistan." Arabian Journal of Business and Management Review (Nigerian Chapter). Vol. 3, No. 10, 2015

Rosalendro Eddy Nugroho is currently a fulltime senior lecturer in Master Program in Post-Graduate Management from Universitas Mercu Buana Jakarta. He holds a Bachelor of Science degree in Chemichal Engineering from Gadjah Mada University, Master of Management from
Universitas Satyagama Jakarta, and $\mathrm{PhD}$ in Management from Bogor Agriculture University. He has taught courses in operation management, supply chain management, enterprise resource planning, Quality Assurance Management, Heath Safety \&Enviroment Mangement, Investation \&Financial Management and managerial economic

Farida Elmi is currently a fulltime senior lecturer in Master Program in Post-Graduate Management from Universitas Mercu Buana Jakarta.

Wahyu Oktri Widyarto is currently a fulltime senior lecturer in under graduate Program in Industrial Engineering Department from Universitas Serang Raya (UNSERA), Banten. 